\title{
Postcolonial nation-building and health in Indonesia
}

\author{
Saúde e construção da nação na Indonésia pós-colonial
}

\author{
Eric Carter \\ Geography Department/Macalester College. \\ Saint Paul - MN - USA \\ ecarter@macalester.edu
}

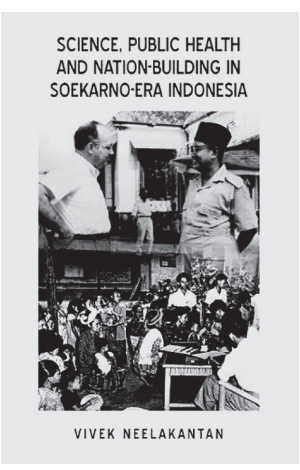

NEELAKANTAN, Vivek. Science, public health, and nation-building in Soekarno-era Indonesia. Newcastle-Upon-Tyne: Cambridge Scholars Publishing. 2017. 237p.
Tn the growing scholarship on international health in the twentieth century, Indonesia has received relatively little attention, given the size of its population (roughly 260 million people) and its impressive development trajectory. Vivek Neelakantan's new book, focusing on the public health politics of Indonesia between 1945 and 1967, shows that the Indonesian case is valuable for sharpening our understanding of how international health and development institutions functioned in newly decolonized states under the geopolitical conditions of the early Cold War. The book also provides instructive points of comparison for scholars of the history of medicine and public health in Latin America during the same era.

The book's temporal scope coincides with the first two decades of the autonomous Indonesian state, dominated by the figure of President Soekarno, who led the struggle for independence from the Netherlands. Soekarno provided the philosophical underpinnings that guided the critical task of nation-building, the leitmotif of

Neelakantan's narrative. At independence, Indonesia was a vast archipelago, home to diverse ethnic, linguistic, and religious groups; yet during the colonial era, power had been concentrated in the island of Java, with the corresponding neglect of many so-called "Outer Islands." The doctrine of pembangunan, devised by Soekarno, "sought to unify the country's centrifugal forces through a common project of shared national modernity" (Neelakantan, 2017, p.19). This appraisal of Indonesia's internal challenges to unity was coupled with a foreign relations stance known as the "Bandung Spirit" (or the "Bandung approach"), which called for the country's "technological self-sufficiency, non-alignment and solidarity with nations in a similar position" - that is, the recently decolonized nations of what would come to be known as the Third World (p.19). Out of necessity, Neelakantan simplifies Indonesia's political history, but argues convincingly that public health work, the organization of a national health care system, and the development of the medical 
profession were all conditioned by the overpowering logic of forming the nation under precarious local and international conditions.

With all the major players in the health sector fully behind the nationalist project, Neelakantan finds a different point of tension to drive the narrative: namely, the contrast between holistic, social medicine-oriented approaches to health planning and the reductionist, vertically oriented strategies promoted by the WHO, the US, and other actors in international health in the post-Second World War era. Thus, Neelakantan situates Indonesia in a well-known metanarrative about the technopolitics of post-war international health (Birn, 2009; Packard, 2016). Yet the particulars of social medicine's emergence in Indonesia are interesting, since it initially arose in the 1930s as a nationalist critique of European colonial medicine. After independence, social medicine harmonized with a nationalist agenda that combined biopolitics (strengthening the citizenry to make development possible) and social justice (offering all Indonesians a basic quality of life, free from poverty, disease, and malnutrition).

However, as discussed in detail in chapter four, international aid programs favored vertically oriented campaigns against the country's "big four" endemic infectious diseases: malaria, yaws, tuberculosis, and leprosy. Control of all these diseases was suddenly made possible by technological and pharmaceutical remedies (such as DDT spraying for malaria and antibiotics for the others). Yaws and leprosy, particularly, were "diseases at the end of the road" that tended to afflict the most remote and inaccessible parts of the country. And all these campaigns were meant to demonstrate the Indonesian state's power to penetrate the far reaches of the archipelago, with humanitarian and state-building objectives apparently coinciding. Except for leprosy, these campaigns were supported by international aid programs that Indonesia played some role in designing, through its active influence in the Southeast Asia Regional Office (SEARO) of the WHO.

Under long-time Minister of Health Johannes Leimena, the national public health strategy went beyond infectious disease control campaigns towards programs to improve maternal and child health and to build a larger cadre of medical professionals to serve national needs. Under Dutch colonial rule, there had been little effort to produce local physicians. Astonishingly, during the 1950s Indonesia's three medical schools produced only about 30 graduates per year, in a country of some 80 million inhabitants. The Dutch-German model of medical education which prevailed in Indonesia was a "rigorous" system that rewarded brilliant and dedicated students, but favored theory over practice, neglected the value of critical thinking and collaborative problem-solving efforts, and suffered from extraordinarily high rates of attrition. Starting in 1954, with help from the International Cooperation Administration (the predecessor of USAID), the medical school of Universitas Indonesia (in Jakarta) entered into a cooperative agreement with the University of California-San Francisco (UCSF) to refashion the medical curriculum according to the American model. While the new system significantly increased the number of medical graduates, it did not solve the problem of inadequate distribution of physicians. They continued to congregate in Jakarta and other large cities on the island of Java, an issue that only began to be ameliorated with the construction of new state medical schools on the outlying islands. Ultimately, the affiliation with UCSF disintegrated in the late 1960s 
and the Dutch-German model was revived. Neelakantan mainly ascribes this failure to the poor fit of American medical training within the broader Indonesian educational system, although there were also financial and political problems.

Much of Indonesia's public health history will sound familiar to students of Latin America, including the strident nationalist rhetoric behind health reforms, the challenges of navigating geopolitical waters to procure international aid while preserving national sovereignty, and the concentration of health services in metropolitan settings at the expense of peripheral regions. Reasons for the failure of the national malaria eradication campaign - a combination of logistical flaws, mosquito resistance to DDT, and rising local opposition - are consistent with the experience of countries like Mexico in the 1960s (Cueto, 2007). The urgency of public health efforts within a nationalist, postcolonial political project in Indonesia evokes scenes of post-revolutionary Cuba (leaving aside Soekarno's rigid anti-communism). It is also interesting to compare the SEARO with the PAHO (Pan American Health Organization) in the same era. While PAHO activities were still strongly determined by the interests of the American regional hegemony, the WHO's regional office for Southeast Asia was perhaps more responsive to the desires of regional states, which used multilateral institutions strategically in postcolonial geopolitics (Amrith 2006; Saavedra 2017).

There are other intriguing differences between Indonesia and Latin America. For one, the simple difference in the timing of political independence (the early 1800s for most of Latin America, the 1940s for Indonesia) meant that the project of developing national biomedical and other sciences was quite delayed for Indonesia; thus, in comparison to countries like Argentina, Chile, Brazil, or Uruguay, the medical profession in Indonesia apparently had little social status and political influence. In all, the state of medicine and health infrastructure was absolutely dire in Indonesia at independence, making its later achievements all the more impressive, although Neelakantan is much more gloomy in his assessment of Indonesia's public health progress in the book's Conclusion. His overall assessment of the Soekarno era, to be "remembered in the history of Indonesian health as an era of bold plans and unfulfilled aspirations" (Neelakantan, 2017, p.210), seems unfair, given the tangible progress that was made in reducing infant mortality and reducing the burden of infectious diseases, which Neelakantan himself mentions, under the challenging circumstances of an impoverished and recently independent nation-state. Nevertheless, this book is recommended for those who seek a more complete understanding of the politics of international health during the early Cold War era. Building particularly on the work of Sunil Amrith, Neelakantan shows how countries undergoing decolonization, like Indonesia, managed to coordinate with one another to capitalize on the new opportunities created by more robust international institutions to serve their own economic and social development objectives, not just the interests of the era's geopolitical superpowers. 


\section{REFERENCES}

AMRITH, Sunil.

Decolonizing international health: India and Southeast Asia, 1930-65. Basingstoke: Palgrave Macmillan. 2006.

BIRN, Anne-Emanuelle.

Making it politic(al): closing the gap in a generation: health equity through action on the social determinants of health. Social Medicine, v.4, n.3, p.166-182. 2009.

CUETO, Marcos.

Cold war, deadly fevers: malaria eradication in Mexico, 1955-1975. Washington, D.C.: Woodrow Wilson Center Press. 2007.
NEELAKANTAN, Vivek.

Science, public health, and nation-building in Soekarno-era Indonesia. Newcastle-Upon-Tyne: Cambridge Scholars Publishing. 2017.

PACKARD, Randall M.

A history of global health: interventions into the lives of other peoples. Baltimore: Johns Hopkins. 2016.

SAAVEDRA, Monica.

Politics and health at the WHO Regional Office for South East Asia: the case of Portuguese India, 1949-61. Medical History, v.61, n.3, p.380-400. 2017. 